\title{
Nickel-Catalyzed Asymmetric C-H Functionalization of Pyridones
}

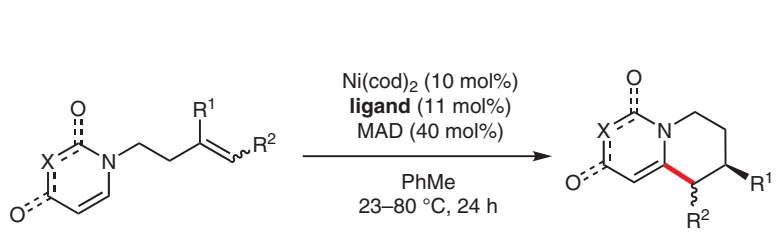

MAD = methylaluminum bis(2,6-di-tert-butyl 4-methylphenoxide)

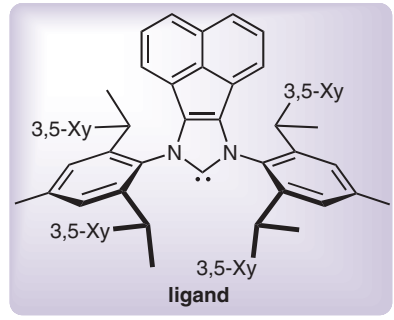

Selected examples:

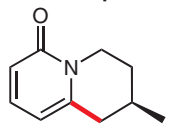

$83 \%$ yield

er $=96: 4$<smiles>CC1=CC[C@H](C2CCn3c(cccc3=O)C2)CC1</smiles>

$90 \%$ yield

$\mathrm{er}=97.5: 2.5$<smiles>C[C@@H]1CCCn2c1cccc2=O</smiles>

$66 \%$ yield

er $=87: 13$<smiles>Cn1c(=O)cc2n(c1=O)CC[C@H](c1ccccc1)C2</smiles>

$91 \%$ yield er $=95: 5$

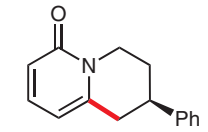

$80 \%$ yield

er $=99: 1$<smiles>CC1=CC[C@H](C2CCn3c(cccc3=O)C2)CC1</smiles>

$86 \%$ yield

$\mathrm{er}=98.5: 1.5$<smiles>O=c1cccc2n1CCC[C@H]2c1ccccc1</smiles>

$77 \%$ yield

er $=50: 50$

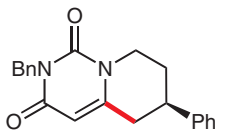

$86 \%$ yield

er $=98: 2$<smiles>O=c1cccc2n1CC[C@H](P)C2</smiles>

$75 \%$ yield er $=99: 1$<smiles>O=c1c2ccccc2cc2n1CC[C@H](c1ccccc1)C2</smiles>

$87 \%$ yield

er = 99:1

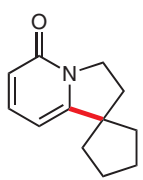

$74 \%$ yield

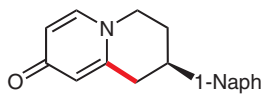

$51 \%$ yield er $=96: 4$

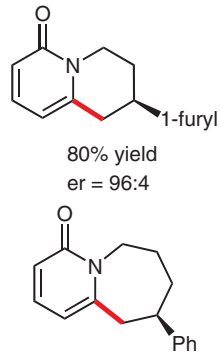

$82 \%$ yield

er $=95: 5$

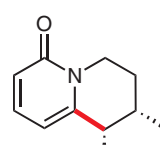

$42 \%$ yield

er $=89: 11$

cis/trans = 11:

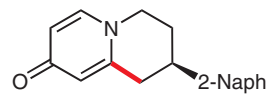

$58 \%$ yield er $=99: 1$
Significance: Chiral pyridone backbones can be found in many bioactive compounds. The authors have developed a nickel-catalyzed enantioselective $\mathrm{C}-\mathrm{H}$ functionalization of 2- and 4-pyridones by using a bulky $\mathrm{N}$-heterocyclic ligand.
Comment: This nickel-catalyzed reaction permits the enantioselective intramolecular $\mathrm{C}-\mathrm{H}$ functionalization of 2- and 4-pyridones. The nickel complex, based on a chiral bulky $\mathrm{N}$-heterocyclic ligand, is effective in terms of selectivity, giving chiral 2- and 4-pyridones in good yields and with high enantioselectivities.

N-heterocyclic

carbenes

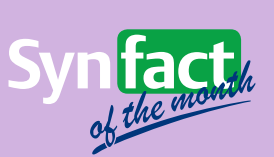

